\title{
Laporan Kasus: Ekstraksi Gigi dengan Perubahan Matriks Tulang sebagai Persiapan Pembuatan Gigi Tiruan Lengkap
}

(Case Report: The Extraction of Teeth with the Change of Bone Matrix as a Preparation for Complete Denture Prosedure)

Fadhila Nurin Shabrina', Bambang Tri Hartomo'

1 Jurusan Kedokteran Gigi, Fakultas Kedokteran, Universitas Jenderal Soedirman,Purwokerto

\begin{abstract}
Abstrak
Pasien pada kelompok usia lanjut memiliki risiko lebih tinggi untuk mengalami masalah kesehatan gigi dan mulut, karena pada usia lanjut, karies dan jaringan periodontal umumnya lebih parah dan progresif. Proses penuaan menyebabkan perubahan struktur dan penampilan gigi, mukosa mulut, penurunan fungsi kelenjar ludah, dan hilangnya mineral tulang melalui resorpsi matriks tulang. Terjadinya resorpsi matriks tulang mengakibatkan kelompok lansia lebih sering mengalami kehilangan gigi yang dapat diperparah dengan terjadinya penyakit periodontal. Setelah pencabutan gigi, kondisi ini perlu diperhatikan oleh dokter gigi agar gigi tiruan yang dibuat nantinya memiliki retensi dan stabilisasi yang baik serta tetap nyaman digunakan oleh pasien. Tujuan kajian kasus ini untuk memberikan gambaran tentang prosedur pencabutan gigi dengan perubahan matriks tulang sebagai persiapan perawatan gigi tiruan lengkap prostodontik. Seorang pasien wanita berusia 56 tahun datang ke RSGM Unsoed ingin memesan gigi tiruan lengkap agar gigi yang tersisa harus dicabut. Pasien merasa tidak nyaman dan kesulitan saat makan dan minum. Pemeriksaan intraoral, hanya gigi 16 yang tersisa dengan resesi gingiva. Kondisi tulang alveolar pasien menunjukkan cenderung mendatar di daerah posterior edentulous. Kasus pencabutan pada pasien usia lanjut harus dilakukan sesuai prosedur yang benar dengan trauma yang minimal agar tidak merusak jaringan pendukung di sekitar gigi dan mempermudah proses perawatan gigi tiruan.
\end{abstract}

Kata kunci: Ekstraksi, Gigi Tiruan Lengkap, Matriks Tulang Alveolar, Pasien Lansia

\section{Abstract}

Patients in the elderly group have a higher risk for dental and oral health problems because in old age, caries and periodontal tissue are generally more severe and progressive. The aging process causes changes in the structure and appearance of the teeth, the oral mucosa, the decline in function salivary glands, and loss of bone minerals through bone matrix resorption. The occurrence of bone matrix resorption results in the elderly group more often experiencing tooth loss which can be exacerbated by the occurrence of periodontal disease. After tooth extraction, this condition needs to be considered by dentist so that the denture made later has good retention and stabilization and remains comfortable for the patient to use. The aim was providing an overview regarding the procedure of extraction teeth with the change of bone matrix as a preparation for the prosthodontic complete dentures treatment. A 56-year-old female patient came to RSGM Unsoed wanted to order complete dentures so that the remaining teeth shoul be extracted. Patient feels discomfort and difficulties when eating and drinking. Intraoral examination, only teeth 16 were left with gingival recession. The patient's alveolar bone condition showst ends to be flat in the edentulous posterior area. The extraction case in elderly patients must be carried out according to the right procedure with minimal trauma so as not to damage the supporting tissue around the tooth and facilitate the process of denture treatment.

Keywords: Alveolar Bone Matrix, Complete Denture, Elderly Patients, Extraction,

Korespondensi (Correspondence) : Bambamg Tri Hartomo. Jurusan Kedokteran Gigi, Fakultas Kedokteran, Universitas Jendral Soedirman. Jl.Dr. Suparno, Purwokerto, Jawa Tengah. Email: bambang.hartomo@unsoed.ac.id

Ekstraksi gigi adalah tindakan perawatan yang cukup sering dilakukan oleh seorang dokter gigi. Tindakan Ekstraksi merupakan pengambilan gigi beserta akar gigi dari soketnya melibatkan jaringan tulang dan jaringan lunak dalam rongga mulut dan prosesnya bisa ditemui faktor penyulit seperti adanya gerakan dari rahang bawah dan bibir.' Jumlah gigi yang dilakukan ekstraksi atau pencabutan gigi dalam suatu populasi dapat menjadi tolak ukur penting dalam menentukan derajat kesehatan gigi dan mulut karena umumnya kondisi gigi yang dicabut merefleksikan adanya penyakit karies gigi dan penyakit periodontal yang sudah tergolong berat. Ekstraksi gigi juga dapat digunakan sebagai tolak ukur tingkat pengetahuan dan motivasi masyarakat dalam mempertahankan giginya. Semakin tinggi angka pencabutan di suatu komunitas masyarakat, maka ditengarai semakin rendah tingkat pengetahuan dan motivasi masyarakat dalam bidang kesehatan gigi dan mulut di daerah tersebut.2,3 Ekstraksi lebih banyak dilakukan oleh pasien ada kelompok usia lanjut (lansia) dibandingkan dengan kelompok usia lainnya. . $^{3,4}$

Kelompok pasien usia lanjut memiliki peningkatan kerentanan terhadap masalah kesehatan gigi dan mulut. Di sisi lain, proses penuaan secara fisiologis menyebabkan terjadinya perubahan struktur dan tampilan gigi geligi, struktur gigi menjadi semakin rapuh akibat atrisi, erosi, ataupun abrasi, mukosa oral semakin tipis, halus, dan kering sehingga rentan terhadap trauma, penurunan fungsi kelenjar ludah, dan hilangnya mineral tulang melalui resorbsi matriks tulang. Terjadinya 
resorpsi matriks tulang mengakibatkan kelompok pasien usia lanjut lebih sering mengalami kehilangan gigi dibandingkan kelompok usia lainnya karena diperparah dengan terjadinya perubahan pada jaringan periodontal karena faktor fisiologis maupun faktor penyakit sistemik. ${ }^{5}$

Setelah gigi tanggal, perlu dilakukan perawatan rehabilitatif. Pasien kelompok usia lanjut cenderung lebih memilih perawatan rehabilitatif, berbeda dengan pasien usia muda yang lebih memilih perawatan preventif. ${ }^{4}$ Pembuatan gigi tiruan merupakan suatu perawatan rehabilitatif yang bertujuan untuk menggantikan fungsi gigi yang hilang serta mempertahankan kesehatan jaringan pendukung disekitarnya agar tetap dalam keadaan optimal guna mencegah kerusakan lebih lanjut. ${ }^{6}$ Kehilangan gigi sangat berpengaruh dengan kesehatan pasien secara langsung, salah satunya adalah pemenuhan kebutuhan gizi. 3,7

Tujuan kajian kasus ini untuk memberikan gambaran prosedur ekstraksi dengan kondisi perubahan matriks tulang posterior pada pasien lansia sebagai persiapan pembuatan gigi tiruan lengkap sesuai dengan prosedur yang telah ditetapkan serta untuk menekankan pada pembaca bahwa setelah dilakukannya pencabutan gigi, sebaiknya dilakukan prosedur rehabilitasi, sesuai dengan rencana perawatan yang dirumuskan.

\section{LAPORAN KASUS}

Seorang pasien wanita berusia 56 tahun datang ke RSGM Unsoed ingin dibuatkan gigi tiruan lengkap sehingga ingin mencabut sisa giginya. Pasien merasa tidak nyaman dan kesulitan saat makan dan minum. Pada pemeriksaan intraoral, terlihat hanya tersisa gigi 16 dengan resesi gingiva. Lima tahun sebelumnya pasien pernah ke RSGM untuk mencabut gigi 31, 32, 41, dan 42 namun belum dibuatkan gigi tiruan. Kondisi tulang alveolar pasien menunjukkan gambaran normal pada area edentulous anterior, tetapi cenderung datar pada area edentulous posterior. Keadaan umum pasien baik, pasien mengaku tidak memiliki riwayat penyakit sistemik, pasien memiliki riwayat alergi amoxicillin dan asam mefenamat. Tekanan darah pasien 110/80 mmHg (gambar 1 dan 2).

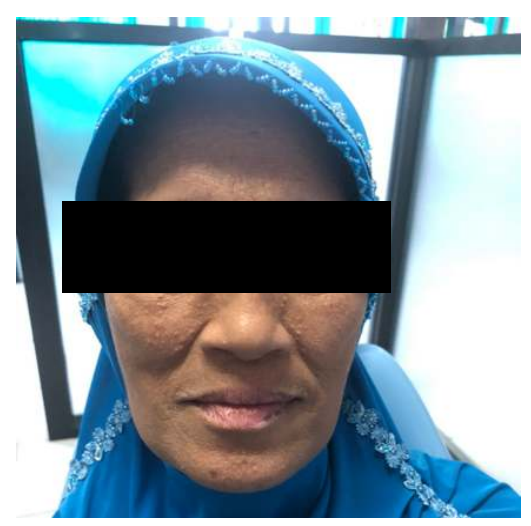

Gambar 1. Foto Klinis Pasien Sebelum Ekstraksi

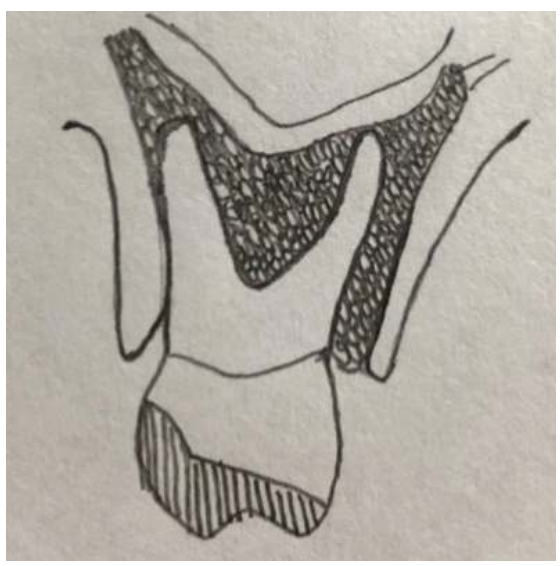

Gambar 2. Sketsa kasus ekstraksi gigi 16

\section{TATALAKSANA KASUS}

Tatalaksana kasus yang dilakukan diawali dengan pemeriksaan subyektif, pemeriksaan obyektif, menentukan asesmen beserta diagnosis, menetapkan rencana perawatan, dan melakukan prosedur ekstraksi yang meliputi preoperatif, perioperatif, dan postoperatif. Berdasarkan pemeriksaan subyektif, diketahui bahwa pasien merupakan pasien perempuan berusia 56 tahun. Keluhan utama pasien yaitu ingin dibuatkan gigi tiruan lengkap sehingga ingin mencabut sisa gigi belakang atas kanannya. Riwayat keparahan penyakitnya, pasien merasa tidak nyaman dan kesulitan saat makan dan minum. Riwayat medis pasien menunjukkan kondisi umum pasien baik, tidak memiliki riwayat penyakit sistemik, tetapi pasien memiliki alergi terhadap amoxicillin dan asam mefenamat. Riwayat dental pasien menunjukkan bahwa pasien sudah pernah ke RSGM sebelumnya untuk melakukan pencabutan gigi 31,32,41, dan 42. Riwayat keluarga dan riwayat sosial pasien tidak diketahui.

Pemeriksaan obyektif menunjukkan bahwa keadaan umum pasien baik atau dapat dikategorikan compos mentis, tekanan darah pasien $110 / 80 \mathrm{mmHg}$ atau dapat dikategorikan normal, pemeriksaan ekstraoral pasien tidak ada keterangan, dan pemeriksaan intraoral menunjukkan hanya tersisa gigi 16 dengan resesi gingiva dengan palpasi (-), perkusi (-), mobilitas (-), vitalitas (-). Kondisi tulang alveolar pasien menunjukkan gambaran normal pada area edentulous anterior, tetapi cenderung datar pada area edentulous posterior. Berdasarkan pemeriksaan subyektif dan obyektif yang telah dilakukan, disimpulkan assesmen atau diagnosis pasien tersebut yaitu nekrosis pulpa gigi 16 dengan rencana perawatan ekstraksi gigi 16 dengan anestesi infiltrasi untuk menganestesi nervus alveolaris superior posterior dan nervus palatinus mayor. 
Tatalaksana kasus pasien meliputi tahapan praoperatif, perioperatif, dan pascaoperatif. Pada tahap Praoperatif, asisten operator menyiapkan alat dan bahan. Alat-alat yang digunakan adalah oral diagnostic set yang meliputi kaca mulut, pinset, sonde, dan eksavator, bein, dan tang cabut molar RA kanan (memiliki takik pada bagian bukal). Sedangkan bahan yang digunakan meliputi APD berupa masker, handscoon, nurse cap, dan face shield, povidone iodine, pehacaine ampul, spuit, kassa, cotton ball, saline steril, dan tampon. Posisi operator dengan posisi ekstraksi regio 1 yaitu dari antara arah jam 6 sampai 9 dengan posisi pasien semisupine. Posisi tangan bebas dengan pinch grasp dan posisi memegang alat pen grasp. Operator juga menjelaskan prosedur yang akan dilakukan pada pasien dan melakukan informed consent.

Tahapan Perioperatif diawali dengan melakukan prosedur asepsis dengan menggunakan cotton pellet dan povidone iodine dengan gerakan sirkuler. Kemudian dilakukan prosedur anestesi untuk menganestesi nervus alveolaris superior posterior dan nervus palatinus mayor, dilanjutkan dengan massage daerah anestesi, tunggu hingga terlihat mukosa putih atau pucat dan pasien mulai merasa baal. Lakukan tes anestetikum pada daerah sulkus gigi yang akan diekstraksi. Adaptasi tangan bebas atau stabilisasi untuk melakukan ekstraksi gigi rahang atas, teknik yang digunakan adalah pinch grasp. Melakukan luksasi gigi 16 menggunakan elevator dengan metode paralel hingga akar gigi mengalami kegoyangan dan terpisah dari soket. Langkah berikutnya adalah melakukan pencabutan gigi dengan menggunakan tang cabut rahang atas posterior dengan gerakan bukalpalatal-rotasi-ekstraksi. Setelah gigi lepas dari soket, dilakukan pemeriksaan pada soket gigi adakah fragmen gigi yang tertinggal atau tulang yang tajam, menggunakan kuret. Lakukan penghalusan tulang menggunakan bone file jika ditemukan tulang tajam. Spooling dengan povidone iodine dan saline steril. Kompresi atau menekan area bekas pencabutan dengan menggunakan tampon.

Prosedur postoperatif dilakukan dengan memberikan medikasi berupa antibiotik clindamycin dan analgetik anti inflamasi kalium diklofenak. Pasien diinstruksikan apabila terjadi perdarahan, dapat diatasi dengan melipat kassa, kemudian menaruhnya di atas luka bekas pencabutan dan digigit selama 30 menit sampai 1 jam sesudah pencabutan. Hal ini dilakukan karena kassa dapat memacu terjadinya beku darah dan melindungi dari perdarahan lanjutan. Pasien diinstruksikan juga untuk diet lunak dan menghindari makan makanan yang keras karena dapat menyebabkan kerusakan pada daerah pencabutan. Kemudian, pasien diinstruksikan untuk tidak menghisap daerah bekas pencabutan, meludah terlalu sering, mengunyah permen karet, dan memberikan rangsangan panas pada daerah wajah dekat daerah pencabutan. Operator juga memberikan DHE/KIE pasca pencabutan mengenai pemeliharaan oral hygiene. Pasien diingatkan agar tidak berkumur pada 24 jam pertama pasca pencabutan.

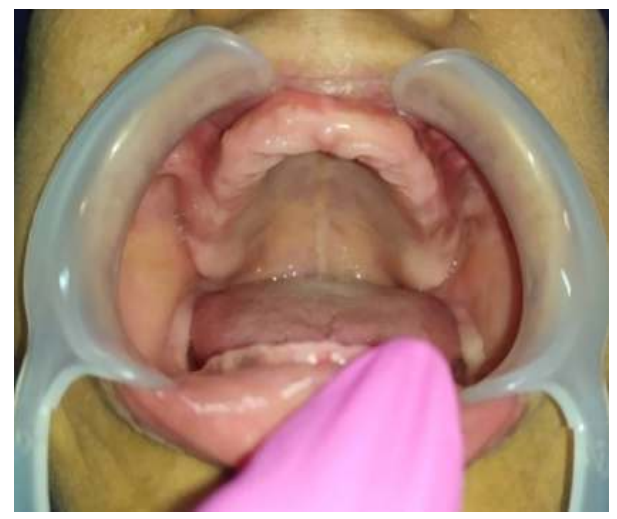

Gambar 3. Post-ekstraksi 16

Pasien dapat berkumur dengan air garam 3 kali sehari selama 3-4 hari. Gigi dapat dibersihkan menggunakan sikat gigi dan dental floss, namun harus menghindari daerah pencabutan. Operator juga memberikan penjelasan pada pasien untuk mulai melakukan prosedur pembuatan gigi tiruan lengkap 3 bulan setelah dilakukannya ekstraksi, karena pada kasus ini, ekstraksi gigi 16 merupakan ekstraksi terakhir yang dilakukan pasien (Gambar 3). Prosedur pembuatan gigi tiruan lengkap dilakukan 3 bulan pasca ekstraksi dengan harapan penutupan luka bekas ekstraksi sudah sembuh dengan sempurna dan sudah tidak terjadi resorpsi tulang alveolar sebagai respon pasca ekstraksi secara agresif, sehingga GTL yang dibuat dapat digunakan secara nyaman dan sesuai dengan anatomi yang ada.

\section{PEMBAHASAN}

Ekstraksi gigi merupakan prosedur pengambilan gigi dari soketnya karena sudah tidak dapat dilakukan perawatan lainnya. Ekstraksi gigi juga merupakan tindakan pembedahan yang melibatkan jaringan keras dan jaringan lunak rongga mulut. Idealnya, prosedur ini dilakukan secara utuh, dari mahkota hingga akarnya, dengan trauma seminimal mungkin terhadap jaringan pendukung gigi disekitarnya, sehingga luka bekas pencabutan dapat sembuh dengan sempurna tanpa meninggalkan komplikasi.., 9

Indikasi dilakukannya pencabutan gigi di antaranya adalah akibat kelainan atau penyakit periodontal dan sebagai tindakan praprostetik atau mouth preparation pembuatan protesa. 10 Pada laporan kasus ini menunjukkan bahwa pilihan perawatan yang diberikan pada pasien sudah sesuai indikasi. Tatalaksana kasus yang dilakukan juga sudah sesuai dengan tatalaksana kasus pencabutan yaitu meliputi tindakan praoperatif, 
perioperatif, dan pascaoperatif. Hal ini sejalan dengan jurnal Halaszynski yang menyatakan bahwa prosedur ekstraksi meliputi praoperatif berupa persiapan tindakan yang dapat dilengkapi dengan pemeriksaan laboratorium jika diperlukan, perioperatif yaitu saat prosedur anestesi hingga keluarnya gigi dari rongga mulut, dan tindakan postoperatif yang meliputi instruksi, edukasi, dan medikasi yang sesuai."

Setelah melakukan tindakan ekstraksi, pasien juga akan melakukan pembuatan gigi tiruan lengkap (GTL). Pembuatan gigi tiruan lengkap dilakukan minimal 3 bulan pasca ekstraksi, sehingga luka pasca ekstraksi dapat menutup secara sempurna dan diharapkan tidak terdapat perubahan pada jaringan pendukung gigi. Pembuatan gigi tiruan harus dilakukan guna menggantikan struktur yang hilang, memperbaiki fungsi mastikasi, estetik, dan fonetik penderita. Keadaan edentulous pasien yang tidak dilakukan perawatan rehabilitatif memiliki resiko terjadinya resorpsi tulang alveolar yang lebih tinggi. Hal ini disebabkan karena tidak terpicunya proses osteogenesis tulang yang biasanya terjadi ketika gigi masih berada dalam rongga mulut dan aktif melakukan fungsi pengunyahan, berbicara serta berperan dalam sistem stomatognati. 10

Tindakan ekstraksi gigi yang dilakukan akibat kelainan atau penyakit periodontal dan sebagai persiapan pembuatan gigi tiruan lengkap merupakan hal yang sering terjadi. Pelaksanaan kasus ekstraksi dalam hal ini harus dilakukan sesuai dengan prosedur yang tepat dengan minimal trauma agar tidak merusak jaringan pendukung di sekitar gigi tersebut, karena dalam pembuatan gigi tiruan atau piranti prostodontik lainnya, jaringan pendukung rongga mulut sangat berpengaruh terhadap tingkat keberhasilan dan tingkat kenyamanannya. Disarankan dokumentasi dilakukan dengan baik pada setiap tahap agar mempermudah memberikan gambaran pada pembaca terkait prosedur ekstraksi yang dilakukan.

\section{DAFTAR PUSTAKA}

1. Sakar O. Removable PartialDentures: A Practioner's Manual, Springer International Publishing, USA. 2016.

2. Silva MF., Correia AC., Batista MJ., Rosario ML. Oral Health Condition and
Reasons for Tooth Extraction Among An Adult Population (20-64 years old), Departemen de Odontologia Socia, Brasil. 2005; (22): 8.

3. Sari M., Sumarsongko T. Penatalaksaan Lingir Datar pada Pembuatan Gigi Tiruan Penuh dengan Teknik Pencetakan Mukodinamik, ISSN, Bandung. 2016; (1): 1.

4. Fithri Z., Rochim A., Cholid Z. Distribusi Pencabutan Gigi Berdasarkan Karakteristik Sosiodemografi pada Pasien RSGM Universitas Jember Periode Januari-Desember 2014, e-Jurnal Pustaka Kesehatan, Fakultas Kedokteran Gigi Universitas Jember. 2017; (5):1.

5. Feng L., Wang H., Lin M.Effect of Painless STA on Tooth Extraction of Elderly Patients With Periodontal Disease, Experimental and Therapeutic Medicine, China. 2017; (15): 7.

6. Ariestania V. Immediate Full Denture Untuk Perbaikan Estetik dengan Alveolektomi Radikal pada Rahang Bawah, Denta Journal, Fakultas Kedokteran Gigi Hang Tuah. 2015; (9): 2.

7. Patel J., Jablonski RY., Morrow LA. Complete Dentures: An Update On Clinical Assesment and Management: Part 1, British Dental Journal. 2018; (19): 18.

8. Samman AA., Mohamad BS., Sami GM., Hamakhan RI. Developmental of Tooth Extraction Anxiety Scale: A Proposal of New Scale, International Journal of Dentistry and Oral Health. 2019; (5): 9.

9. Prayudha A., Simandjuntak RM., Sumarta NPM. Musculoskeletal Disorder Risk Level Evaluation of Posterior Maxillary Tooth Extraction Procedures, Dental Journal. 2019; (52): 1.

10. Oktaria I., Shen R. The Prostodontics Care For Geriatric Patients Nowadays, Journal of Indonesian Dental Association. 2019; (18): 2.

11. Halaszynski TM. Preoperative Assesment and Evaluation for Maxillofacial Surgery, Springer International Publishing. 2018; (57): 9. 